\title{
A MULHER E A EDUCAÇÃO DA CRIANÇA PEQUENA FORA DO ESPAÇO DOMÉSTICO: QUESTÕES E DESAFIOS
}

\author{
EDUCACIÓN DE MUJERES Y NIÑOS PEQUEÑOS FUERA DE LA CASA: PROBLEMAS Y \\ DESAFÍOS
}

\section{WOMAN AND SMALL CHILD EDUCATION OUTSIDE THE HOUSE: ISSUES AND CHALLENGES}

DOI: http://dx.doi.org/10.9771/gmed.v11i2.28524

\author{
Ana Lúcia Soares da Conceição Araújo ${ }^{1}$
}

\begin{abstract}
Resumo: O presente artigo como um recorte da dissertação defendida em 2007 busca trazer um escopo teórico sobre a política educacional para a criança pequena, trazendo os desdobramentos das lutas travadas pelo movimento feminista, assim como, o Estado como palco de jogos de interesses da sociedade capitalista atua nessa correlação de forças antagônicas para garantir um dos direitos básicos: o direito da criança em creches. Aponta na conclusão que este tema é sempre contemporâneo como forma de resistência e afirmação da mulher e da criança como sujeitos sociais.
\end{abstract}

Palavras-chave: Criança; Mulher; Política Educacional; Estado.

Resumen: El presente artículo como un recorte de la disertación defendida en 2007 busca traer un alcance teórico sobre la política educativa para el niño pequeño, trayendo los desdoblamientos de las luchas trabadas por el movimiento feminista y cómo el Estado como escenario de juegos de intereses de la sociedad capitalista actúa en esa correlación de fuerzas antagónicas para garantizar uno de los derechos básicos: el derecho del niño en guarderías. En la conclusión que este tema es siempre contemporáneo como forma de resistencia y afirmación de la mujer y del niño como sujetos sociales.

Palabras clave: Niño; las mujeres; Política Educativa; Estado.

Abstract: The present article as a cut of the thesis defended in 2007 seeks to bring a theoretical scope on the education policy for the small child, bringing the unfolding of the struggles waged by the feminist movement and how the State as a stage of interests of the capitalist society acts in this correlation of opposing forces to guarantee one of the basic rights: the right of the child in day-care centers. It points to the conclusion that this theme is always contemporary as a form of resistance and affirmation of woman and child as social subjects.

Keywords: Child; Woman; Educational politics; State.

\section{Introdução}

Ao contrapor-se aos ideais medievais o projeto da modernidade, ancorado nos pressupostos iluministas: de equidade social, valorização do indivíduo concreto e emancipação política e econômica não atendeu as expectativas humanas a que se propôs. Desde do século XVIII até os nossos dias a modernidade só fez mudar de roupagem e alargar o fosso da desigualdade em todos os ângulos da vida humana. Essa evolução histórica trouxe como conseqüência, uma crise generalizada e falta de esperança por um mundo mais justo e fraterno. 
Vários autores tentam nomear esse mal-estar tentando dar conta das inquietações do homem contemporâneo: "pós-modernidade", "modernidade tardia", "alta modernidade". Seja qual for a sua nomenclatura estamos vivendo um momento histórico de angústias e descrédito nas propostas de dias melhores. Aflições que, ao mesmo tempo, possibilitam os atores sociais da história resistirem, criarem outras formas de luta para garantirem a sua sobrevivência e participação, enquanto seres historicamente situados, que tentam a qualquer preço dirigir e/ou retomar o bonde da história.

Pretendemos a partir de autores como Hobsbawm (1995), Berman (1986), dentre outros que darão subsídios teóricos para discutirmos as aflições desse projeto que ainda não acabou: a modernidade. Apontando perspectivas de luta de resistência e reconhecimento de dois segmentos da sociedade que desde do período greco-romano sempre ficaram a margem de participação social: a mulher e a criança.

Ao referir-me na criança estarei falando da primeira infância - faixa etária de 0 a 06 anos, por ter sido alvo ao longo do século XX de teorias do desenvolvimento e políticas governamentais compensatórias na área educacional com intuito de sanar problemas sociais das crianças pequenas. O objetivo não é encerrar a discussão como se todos os problemas da mulher e da criança já estivessem solucionados, mas refletir como a educação tem posicionado socialmente esses sujeitos na contemporaneidade.

\section{As contradições do projeto da modernidade}

A ordem social de qualquer tempo é fundamentada em pressupostos filosóficos que legitimam e regulam as relações entre os homens e suas instituições. Lyotard (1985), aborda que a filosofia exerce um papel de legitimação dos metadiscursos, trabalhando os jogos de linguagens de modo a otimizar as performances do sistema com eficácia; através de uma trama dialética inconsciente.

Essa premissa deixa transparecer que nenhuma ação é neutra, mas é dotada de intencionalidade seja para libertar ou aprisionar as pessoas. Antes do projeto da modernidade, a religião e a fé dirigiam e definam as atitudes do homem. Na tentativa de retirar da igreja e da força metafísica o poder sobre os homens os ideais iluministas deslocam os desígnios do homem para a razão e cientificidade objetiva, onde o próprio homem poderia tomar suas decisões e fazer a sua história.

Rousseau em seu discurso proferido aos cidadãos de Genebra, em 1750, alerta que o estabelecimento desse convívio em sociedade e a racionalidade nas ações humanas, inicia uma condição desigual e desumana. Tendo, também, na propriedade privada e a noção de governo como forma de sufocar a liberdade do homem natural, dividindo os homens entre governantes e governados, resultando, muitas vezes, em um estado despótico, entre senhores e escravos. Nostalgicamente, ele almejava ter nascido em um país, onde tanto o soberano como o povo pudesse ter um único e um mesmo interesse: a felicidade comum entre os indivíduos.

Para entendermos como se processa a desigualdade entre os homens Rousseau nos convida a conhecer o próprio homem, não o homem civilizado, mas o homem natural. Distanciando-se da razão poderemos, adentrar-nos e compreendermos dois princípios que regem a alma humana: os sentimentos de 
autopreservação que consiste em atitudes de compaixão e o de comiseração que se vale da proteção a outros de sua espécie. Esses valores se perdem um pouco no projeto da modernidade uma vez que o individualismo, preconizado pelo acúmulo de capital e garantia da propriedade privada individual, passa a gerenciar a conduta humana, perdendo a noção de coletividade.

Quando o homem natural passa a agrega-se a outros homens, não só pelas necessidades básicas de caça, pesca e defesa, mas pelo o amor conjugal e paternal. Surge a primeira comunidade: a família, uma tímida noção de propriedade emerge como forma de delimitar papéis sociais. A perfectibilidade humana levou o homem a perceber que os membros do seu próprio grupo familiar uns eram mais fracos, mais hábil, etc., levando a uma disputa.

Apesar de ser considerado um democrata liberal romântico, por considerar que o homem natural era bom. Rousseau nos traz elementos cruciais que nos faz entender a desvirtuação dos ideais iluministas que, posteriormente, foram abarcados pela burguesia com o intuito de manter seus privilégios e fortalecer o discurso para manter-se no comando da nova ordem social. A família, por exemplo, passa a ser fruto da agregação por laços de amor conjugal e paternal, surgindo a primeira forma de determinar o domínio entre os sujeitos de um pequeno grupo social definindo os papéis sociais; delimitando as capacidades masculinas e femininas. Discurso que tentou desde os primórdios da humanidade aprisionar a mulher não como sujeito social pensante e atuante na história, mas como submissa de um discurso paralisante.

Por outro lado, à medida que o capitalismo expandia-se, concomitante a esse discurso, as indústrias modernas precisavam de mais mão-de-obra para alavancar o seu crescimento, forçando a inserção não só de homens no mercado de trabalho como, também, de mulheres. Esse movimento imposto pelas circunstâncias sócio-econômicas geraram no operariado feminino angústias, insatisfação, desejo de realização pessoal e participação política.

Felizmente, como salienta Berman (1986, p. 23) a denuncia da vida moderna é polifônica e dialética, pois os seres humanos buscam os valores negados pela própria modernidade. Homens e mulheres tentam obter soluções e fôlego, acreditando na perspectiva de dias melhores, para os problemas que lhes afetam para "o dia de amanhã e o dia depois de amanhã".

As contradições da modernidade, ainda, segundo Berman levam-nos não só a um desejo de crescer economicamente, mas, sobretudo na possibilidade de crescimento em experiência, conhecimento, na busca de prazer, realização e sensibilidade. Com o objetivo de resgatarmos a "identidade" étnica, nacional, classista, cultural, sexual dentre outras possibilidades que nos identifique no mundo, como sujeitos únicos e plural. Por fim, convida-nos a voltar as nossas raízes para renovarmos e nutrirmos para perigos e aventura da vida que estão por vir (Berman, 1986, p.35).

Para mulher aliar o seu direito à maternidade e a participação social sempre gerou angústias e desafios, não para cruzar os braços, mas para lutar por direitos iguais aos homens e garantias de espaços educativos dignos para os seus filhos, que não possuem idade para agirem por conta própria. O próprio sistema impulsionou a buscá-la alternativas fora do espaço doméstico para educação complementar dos seus filhos. Ao necessitar de mão-de-obra feminina, principalmente as mães pobres que sempre 
precisavam trabalhar, não só para sua emancipação, mas principalmente, para sua sobrevivência, desejavam o reconhecimento social de sua existência.

Essa falsa inserção social não assegurou a equidade social para as mulheres, ao contrário o fosso da desigualdade atingiu a todos sem distinção de gênero. A crise dos Estados-nações que limitou a soberania dos países das sociedades modernas, o estreitamento do tempo-espaço promovido pelo processo chamado de globalização e a grande influência dos organismos multinacionais contribuíram para as condições desumanização.

Segundo Hobsbawn (1995), a tensão do fim do século XX gerou uma ansiedade frente ao processo de globalização acelerado, tanto das instituições públicas como dos seres humanos, por não permitir um tempo de adaptação às mudanças transnacionais. A mais nefasta e cruel consequência foi o individualismo associal absoluto, principalmente, dos países desenvolvidos ocidentais, acarretando a desintegração dos valores de relacionamento humano que privilegiasse o respeito à coletividade social.

Para mulher o acesso ao processo produtivo industrial não era mais assegurado, pois as exigências da "aldeia global" solicitavam pessoas cada vez mais qualificadas. Entretanto a história não permitiu nem deu tempo à mulher desvencilhar-se dos preconceitos e subjugações sociais, possibilitou apenas garantir a sua mínima sobrevivência. Quanto menos a tão sonhada educação para os seus filhos, enquanto estavam fora de seus lares.

\section{A busca de alternativas na contemporaneidade}

As rápidas mudanças mundiais apesar de criarem uma conjuntura de incerteza, acarretando a interconexão sob a superfície da terra de forma desordenada. Além disso, traz nos seus pressupostos filosóficos um descentramento do sujeito estável e fixo proposto pelo iluminismo, ocasionando em identidades, abertas contraditórias, inacabadas e fragmentadas (Hall, 2005, p. 46). Como nenhum poder consegue subjugar o ser humano por muito tempo, mecanismos de enfrentamento são engendrados pelos próprios sujeitos como forma de superação das condições de sua existência.

O engajamento radical constitui uma atitude importante de contestação prática, uma vez que embora estejamos cercados por graves problemas, podemos e devemos nos mobilizar para reduzir o seu impacto, a fim de transcendermos. O movimento social é uma via de acesso importante para a possibilidade de mudanças que atendam aos interesses dos marginalizados pela sociedade.

Os movimentos sociais como ações coletivas de resistência atuam como forma de minimizar as desigualdades sociais, exigindo do poder local alternativas para garantia da sua existência material e subjetiva. Nesse sentido as mulheres aprenderam que para fortalecer e adquirir os seus anseios era preciso se aliar a um movimento político de identificação único, uma vez que as aspirações eram de todas as mulheres. Como corrobora Hall (2005):

Ele (o movimento feminista) questionou a clássica distinção entre "dentro" e o "fora", o "privado" e o "público". O slogan do feminismo era: "o pessoal é político. Ele abriu, portanto, para a contestação política, arenas inteiramente novas de vida social: a família, 
a sexualidde, o trabalho doméstico, a divisão doméstica do trabalho, o cuidados com as crianças (HALL, 2005, p. 45).

Nessa perspectiva, as mulheres foram às ruas manifestarem sua indignação exigindo não só a participação social igualitária ao homem, mas espaços educativos denominados creches para atender os seus filhos enquanto estavam fora do espaço doméstico não como uma troca de favor, através das instituições filantrópicas e política compensatória, que não respeitavam a criança como sujeito, as objeto de manipulação de especialista (Kuhlman, 1990 apud Sanches 2003, 65-63-67). A sociedade precisava envolver no seu projeto de socialização os seus filhos com uma educação de qualidade e não assistencialista, mas com cunho político pedagógico no fazer cotidiano das instituições. A maternidade, por sua vez teria que ser vista como um direito e não uma punição para a negação de realização pessoal e política da mulher.

As creches que emergiram na década de 70 segundo Oliveira (1996) surgiram com o intuito de modelar e padronizar as crianças às propostas que a instituição desejava, não respeitando a singularidade e a pluralidade histórico-cultural das crianças. Atendendo mais uma vez ao projeto de escola da moderna, onde a classificação e o padrão pré-estabelecido burguês servia de parâmetro para a chamada "socialização".

As camadas de prestígio social percebiam a creche como mecanismo de controlar a violência social e erradicação da mortalidade infantil. Dessa forma, camuflava os graves índices de exclusão social, omitindo a raiz dos problemas sociais, que eram a má distribuição de renda, péssimas condições de políticas de saúde publica e o esfoliamento social e afetivo das pessoas dos extratos sociais desfavorecidos.

Segundo Gohn 1985 apud Sanches 2003, o processo de abertura política, sobretudo no Estado de São Paulo, junto às comunidades pobres das periferia foi decisivo. Naquele período, o movimento feminista teve uma atuação marcante na luta contra a carestia e o movimento pela anistia (1973-1978), abriu espaço para a construção de uma luta unificada mais abrangente e concreta por creches; exigindo um redimensionamento do seu papel social enquanto instituição educativa que respeitasse a identidade social, histórica e cultural da criança.

As próprias contradições da pós-modernidade geram desafios no mundo contemporâneo com vistas a resgatar valores perdidos na sociedade moderna como cooperação em detrimento da competição individual ecoam da ação coletiva do movimento feminista, a fim de atender interesses de um grupo social oprimido.

Essa foi uma das saídas encontrada, diria não só pelas mulheres pobres, mas para os homens, também, que devido ao inevitável processo de globalização mundial da economia se viu encurralado frente à maciça exclusão social. Este processo de transformação global, acirrou ainda mais a desigualdade, negando a homens e mulheres pobres condições de garantir o seu sustento cotidiano, para atender as necessidades mínimas de sua família e sua dignidade. A maioria, felizmente, procurou não entrar no submundo do crime, mas apostou na tentativa de uma ação coletiva de resistência e enfrentamento que reformulasse as práticas sociais vigente. 
Nesse sentido recorrem ou fundam associações de bairros para clamarem e exigirem medidas imediatas para os problemas que lhe afligem. A criação de creches comunitárias constitui-se em uma dessas alternativas paralelas aos direitos negados pelas políticas governamentais.

\section{O Estado como mediador da correlações de forças}

O Estado atua nas áreas estratégicas que representam lócus concreto de domínio, desigualdade e insatisfação, assim como nos setores que possuem pertencimento claro e definido, como o bancário e o industrial, que favorecem de forma direta e explícita o desenvolvimento econômico da sociedade. A intervenção estatal nas demandas da realidade social, em diferentes épocas, oscila entre intenção de atender às classes antagônicas em conflitos; ora privilegiando o poder hegemônico, ora atendendo o clamor da classe social e economicamente desfavorecida, a fim de amenizar as tensões.

Segundo Bobbio (1987, p.73), o Estado como ordenamento político nasce da dissolução da comunidade primitiva baseada sobre os laços de parentesco e a formação de comunidade derivadas da junção de vários grupos por razão de subsistência material e defesa contra arbitrariedade externa. $\mathrm{O}$ Estado moderno representa a transição da barbárie para a idade civil, substitui-se o homem natural que agia por seus próprios instintos para ao homem civilizado, denominado de cidadão, passando a ter sua liberdade protegida pelo Estado. A propriedade individual é marco inaugural da atuação do Estado como espaço de forças antagônicas.

Nessa nova forma de organização social de desiguais, emergem também a dicotomia entre público e privado. O Estado, através do contrato social, efetua a mediação para controlar as forças conflitantes entre as classes. Caracteriza-se por relações de subordinação entre governantes e governados, ou seja, na relação entre detentores do poder de comando de um lado e destinatários do dever de obediência do outro (Bobbio 1987, p. 15-16). As concepções de Estado formuladas por Marx e Gramsci esclarecem como, dialeticamente, este movimento entre as classes ocorre.

$\mathrm{Na}$ concepção marxiniana a relação entre Estado e sociedade se inscreve pela liberalização do indivíduo das obrigações feudais e a ingerência dos modos de produção instaurada que fundam a formação contratualista (Marx e Engels ,1998, p. 9-10).

As críticas de Marx ao contratualismo são geradas pelas contradições provocadas pela organização social do capitalismo e pela emersão social e política do trabalhador, denominado por ele na época de proletariado. O Estado, para Marx, possui uma origem alicerçada na desigualdade e no conflito de classes em decorrência do surgimento da propriedade privada, com a função de assegurar e conservar a dominação e a exploração de uma classe sobre a outra (Marx e Engels, 1998, p. 10). Marx percebia uma profunda conexão entre os dois conceitos, por outro lado atribuía à sociedade civil o papel decisivo da relação estabelecida entre sociedade civil e sociedade política.

O Estado, de acordo Marx, constituía-se num instrumento voltado para garantia das próprias bases sobre as quais se apoiariam a sociedade civil. O Estado burguês, por exemplo, protegia as relações capitalistas de produção. De forma a assegurar o domínio do capital sobre o trabalho, a reprodução 
ampliada do capital, a acumulação privada do produto social, a redistribuição do fundo público em benefício do capital etc. Portanto, "o Estado seria, ao mesmo tempo, parte integrante das relações capitalistas de produção e de defesa destas" (Barbosa, p. 160, 2004).

Entretanto, segundo Marx, "o modo de produção da vida material condiciona o processo em geral de vida social, política e espiritual. Não é a consciência dos homens que determina o seu ser, mas ao contrário, é o seu ser social que determina sua consciência" (Marx, 1982, p. 25). Assim sendo, as próprias contradições da vida material, a partir do conflito existente entre as forças produtivas sociais e as relações de produção, poderiam provocar uma ação transformadora dos indivíduos submetidos a uma condição desigual. Uma vez organizados deveriam desenvolver uma consciência de classe liberta dos valores e das concepções burguesas. Por isso, o Estado, na visão de Marx, "desaparecia com o fim da 'pré-história da humanidade', isto é, com o fim da história humana caracterizada pela propriedade privada e pela desigualdade social" (Barbosa, p. 171, 2004).

Com base nas formulações de Marx e Engels sobre o caráter de classe do Estado e o seu papel como afirmação e consolidação do capitalismo, Gramsci conceitua o Estado como "todo complexo de atividades práticas e teóricas com que a classe dirigente justifica e mantém não só o domínio, mas consegue obter o consenso ativo dos governados [ou, ainda, como] organismo próprio de um grupo, destinado à criar as condições favoráveis á expansão máxima deste grupo" (GRAMSCI 1976 apud MACIEL, 2004, p. 221).

Partindo desta definição geral, concebe o Estado não só como aparelho político-jurídico de dominação social, especializado na coerção e repressão, mas também como aparelho ideológico-cultural, capaz de obter o consenso social para a classe dominante. Daí emerge sua teoria de 'Estado ampliado', ou seja, o conjunto articulado entre sociedade política e sociedade civil, que organiza e conecta as diversas faces do sistema de dominação social: "o mundo da produção, a infraestrutura e o mundo da política e da ideologia, a superestrutura” (Maciel, p. 221, 2004).

Para Gramsci, o conceito de Estado em sentido amplo se traduz na articulação entre sociedade civil, por meio dos aparelhos privados de hegemonia e o aparato burocrático civil militar, ou seja o Estado no sentido estrito. Os diversos aparelhos privados de hegemonia são formados pelos partidos, pelos jornais, pelas igrejas, pelas associações etc. Na visão Gramsciana o Estado (sociedade política) e sociedade civil estão ligados como partes de um mesmo sistema de dominação social, cabendo observar como a sociedade civil se insere nesta dinâmica, se conquistando o consenso ou não para o grupo dominante, como afirma Maciel (2004):

Por isso, fazem parte da sociedade civil tanto os aparelhos privados de hegemonia quanto os de contra-hegemonia. Estes encontram-se ligados às classes subalternas e funcionam no sentido de disputar a hegemonia no seio da sociedade, combatendo a visão de mundo dominante, elaborando e propagando uma visão de mundo alternativa e organizando a ação político-prática dos grupos subalternos (MACIEL, p. 223, 2004).

Maciel (2004) ressalta que a distinção de Gramsci entre sociedade política e sociedade civil é estritamente metodológica, pois, na realidade, elas estão 'organicamente’ ligadas. Esta separação é típica da teoria liberal para justificar que a diminuição do Estado e o aumento da sociedade civil poderia gerar 
mais democracia e liberdade. A formulação gramsciana é dialética, não dual na relação das duas esferas na organização social.

Partindo das duas definições esboçadas, deduz-se que a intervenção do Estado na realidade é resultante das correlações de forças engendradas na sociedade. Neste sentido, como corrobora Boneti (2006, p. 76), “o Estado se apresenta como apenas um agente repassador à sociedade civil” das decisões travadas entre os agentes de poder. No bojo deste embate, como Gramsci salientava, coexistem as relações de poder dos grupos econômicos e políticos; classes sociais e demais organizações da sociedade que determinam um conjunto de ações à instituição estatal, a fim de indicar os rumos administrativos, econômicos e políticos para estruturação social.

Conclui-se que o Estado como mediador dos anseios das forças sociais em conflito é o responsável em promover a coordenação do ordenamento legal e implementar as políticas sociais. A educação como uma política social, para ser legitimada como direito de todos cidadãos, necessita da atuação estatal, através das políticas educacionais, para assegurar acesso à esse bem público de forma gratuita e de qualidade. Para a classe que não detém o poder econômico para colocar seus filhos em um espaço educacional privado, condição da maioria da população brasileira, especificamente soteropolitana que é o recorte desse trabalho, torna-se um imperativo de máxima urgência, principalmente, referente ao primeiro nível da educação básica.

Fazer essa ressalva é esclarecer que, apesar de utilizar a máquina governamental, o direito à educação pública, gratuita e de qualidade, não é uma política de governo, mas uma política estatal de caráter permanente que solicita a manutenção do Estado, pois, é o gerenciador político das forças em conflito e o arrecadador dos impostos. Requer, também, o envolvimento contínuo da sociedade civil no intuito de aperfeiçoar o acesso e permanência qualitativa à educação, com pressões para ampliação perante os poderes públicos competentes, indicando e/ou clamando o que precisa ser melhorado para promover a emancipação humana como forma de repasse dos impostos pagos pela maioria da população excluída do bem educativo.

\section{O significado da política social na organização capitalista}

Em diferentes momentos históricos as políticas sociais sofreram oscilações no seu provimento por representar uma faca de dois gumes: servem como condições de sobrevivência precária ou necessária ao trabalhador assalariado e, ao mesmo tempo, desempenham um papel de reguladora das massas, podendo influenciar no fortalecimento e retroalimentação das diversas fases do capitalismo.

Para compreensão da política social na teia que tece a sociedade contemporânea, faz-se necessário (re)atualizar, compreender os conceitos de cidadania e direitos. A relação jurídica do Estado de Direito passaram a gerir a vida do homem urbano, a partir das Cartas Constitucionais francesa e norteamericana e, posteriormente, reafirmada pela Organização das Nações Unidas para escamotear as relações sociais desiguais. Após a II Guerra Mundial, estabeleceu-se, no plano formal, direitos iguais a todos os homens. Esta igualdade formal foi preconizada pela ideia de que o trabalho e a capacidade de cada um 
poderiam promover a igualdade (Manzini-Covre, 2006, p. 16-17).

Neste século, foi substituída pelo lema da "solidariedade" que, na verdade, delega às pessoas a aquisição do bem comum. Estes ideários foram traduzidos em políticas sociais na tentativa de amenizar suas contradições. Como afirma Marx(1818-1833), garante apenas uma "conservação" e "reprodução" da vida do trabalhador de forma precária. Por isso, Marx e Engels (1998) propõem uma outra sociedade:

O que o trabalhador adquire por meio de sua atividade é, pois, o mínimo necessário para conservação e reprodução de sua vida humilde. Nós, de modo algum, temos intenção de abolir esta apropriação pessoal do produto do trabalho, uma apropriação que é feita para manutenção e a reprodução da vida humana e que não deixa excedente algum que conceda poder sobre o trabalho alheio. Queremos apenas abolir o caráter miserável desta apropriação, sob a qual o trabalhador vive, meramente, para aumentar capital e permite-lhe viver somente o quanto o interesse da classe governante requer. (MARX, ENGELS, 1818-1833, p. 34, 1998).

A sociedade moderna reporta-se à noção de cidadania como, apenas, uma forma de aquisição dos direitos civis, políticos e sociais. Manzini-Covre (2006) detalha cada um deles para uma melhor compreensão, entretanto, coexistem interligados. Toda vez que o "direito de dispor do próprio corpo" for cerceado, a exemplo da locomoção e da liberdade de expressão, estamos diante da negação do exercício dos direitos civis.

Os direitos sociais, por sua vez, são aqueles que atendem às necessidades essenciais que repõem a força de trabalho, garantindo a sustentação do corpo humano e que produzem a felicidade: alimentação, habitação, saúde, educação, previdência e outros que produzam a felicidade de se sentir gente (ManziniCovre, p. 11-15, 2006).

Os direitos políticos referem-se à deliberação do homem sobre sua vida, incluindo nesse campo, o direito da livre expressão de pensamento, a prática política nos organismos de representação direta (associação de bairro, sindicatos, partidos, movimentos sociais, escolas) e indireta (parlamento, assembleias), todas as formas de resistência a imposições. A importância do papel dos direitos políticos é que auxiliam na efetivação dos direitos civis e sociais, quando há participação ativa, ampla e crítica na busca de acesso real para todos (Manzini-Covre, p. 11-15, 2006).

Como todos participam de alguma forma na construção das cidades na sociedade capitalista, desde os homens que vendem sua força de trabalho de modo direto aos comerciantes ou grandes industriários, todos, no plano formal, têm o direito de usufruir dos resultados dos lucros da produção. A cidadania é ecoada como se a distribuição e o acesso aos direitos civis, sociais e políticos fossem repartidos, igualitariamente a todas as pessoas, independente de classe, sexo, raça ou cor.

Entretanto, a luta travada entre as correlações de forças econômicas e políticas influenciam ou determinam a obtenção de qualquer desses direitos. Como ressalta a autora: “[...] Nesse contexto está a difícil reflexão: os direitos de uns precisam condizer com os direitos dos outros, permitindo a todos o direito à vida no sentido pleno - traço básico da cidadania” (MANZINI-COVRE, 2006, p.15).

A cidadania é o instrumento e a possibilidade de luta indispensável para concretização dos direitos, a forma como os mesmos são partilhados e a participação efetiva no processo de decisão para auferí-los é o que caracterizará se os sujeitos sociais exerceram a sua função enquanto cidadãos. Em uma 
sociedade que, geralmente, estende a integralidade dos direitos aos proprietários da produção, a sua ação deve ser incorporada no cotidiano, na busca pela dignidade humana.

O grande dilema é: como essa igualdade de direitos é distribuída? E nas mãos de quem fica concentrada a fatia privilegiada do processo de produção? Em que condições de liberdade os trabalhadores e seus filhos se apropriam da sua existência? Vieira (2004, p.12) ressalta dois aspectos importantes para compreensão crítica da política social: 1) a superação de classificar os direitos sociais como estatistas e não estatístas, propondo os primeiros como derivados da ação do Estado e os segundos como provindos dos movimentos sociais, o autor pontua que a realidade é construída pelo homem em cumplicidade e o Estado é a representação dessa sociedade civil.

Expor as políticas sociais a dois pólos, ainda, de acordo com Vieira(2004), propaga discussões estéreis, pois, parafraseando Marx na carta a Paul Anneov cita: “Qualquer que seja a sua forma, o que é a sociedade? O produto da ação recíproca dos homens. São os homens livres de escolher esta ou aquela forma de sociedade? De modo nenhum. Suponhamos uma dada sociedade civil e teremos um dado Estado político que é apenas a expressão oficial da sociedade civil” (Marx apud Vieira, 1971, p.189). O desafio da política social é encontrar um princípio de justiça, mas seja qual for a opção ideológica que assuma, seja da maximização da acumulação ou maximização da equidade, o que se obtém é a modificação relativa do perfil de desigualdade existente (Vieira, 2004, p-12-13).

Sendo assim, as políticas sociais, independente do desenvolvimento econômico da sociedade deveriam ser mantidas pelo poder estatal, pois ele é a representação política das classes que convivem em constante conflito na organização social. O Estado é o espaço onde os problemas e necessidades dessas classes deveriam ser resolvidos de forma equitativa, mas como sabemos, a disputa de poder oferece dois pesos e duas medidas. Um outro importante aspecto a ser levantado é que as políticas sociais asseguram o mínimo para a conservação e reprodução humana, como salientado por Marx e Engels (1998) no Manifesto Comunista. Com base nas duas observações de Vieira (2004), podemos, também, inferir que a configuração e qualidade das políticas sociais são traduzidas, conforme o grau de participação, reivindicação, resistência e intervenção dos membros oprimidos da sociedade civil.

As políticas públicas advindas do Estado, nessa perspectiva, anunciam a correlação de forças em um equilíbrio instável de compromissos, empenhos e responsabilidade sociais. Revela as características próprias de intervenção estatal submetido aos interesses gerais do capital na organização e na administração da coisa pública, contribuindo para assegurar a cooptação e o controle social.

Talvez a luz no fim do túnel ou a esperança de que sempre é possível nadar contra a corrente esteja nas próprias condições de exclusão e injustiça social. Marx e Engels (1998) apontam a possibilidade de superação frente aos obstáculos engendrados dentro da dinâmica dos modos de produção e organização social do sistema, através da luta coletiva desencadeada pelo descontentamento e agregação consciente dos indivíduos subalternizados:

O avanço da indústria, cujo promotor involuntário é a burguesia, substitui o isolamento dos trabalhadores, em virtude da competição, pela combinação revolucionária, devido à associação [...]. O que a burguesia, portanto, produz, acima de tudo, são seus próprios 
coveiros. A sua queda e a vitória do proletariado são igualmente inevitáveis (MARX, ENGELS, 1818-1833, p. 29, 1998).

A expansão da igualdade, liberdade e a realização do bem comum (fraternidade) em seu significado mais verdadeiro - a emancipação humana - poderá ser concretizada com um posicionamento político e consciente das pessoas excluídas, a fim de evitar a aniquilação da vida. O exercício da cidadania só tem sentido quando os indivíduos se engajam coletivamente, não só com intuito de atender às necessidades básicas, sobretudo o acesso a todos os níveis de existência, incluindo o papel de cada pessoa como sujeito na realização de suas conquistas sociais e políticas.

\section{Política educacional: peças do quebra-cabeça da política social}

A política educacional é direcionada por mecanismos "técnicos" que criam diretrizes, sistematizam e regulamentam e, ao mesmo tempo, regulam os conflitos e divergências existentes na tentativa de homogeneizar as ações. A legislação, segundo Martins(1994), funciona como um elemento 'técnico' que diz 'falar pelo povo', exercendo um controle do sistema escolar, visando à sua uniformização no âmbito de uma nação, de um Estado. Nesse sentido, uma das formas de materialização de políticas sociais é a elaboração de leis.

Para entender a política educacional na esteira da política social é preciso analisar a função da educação como um direito importante à vida plena do ser humano e os mecanismos que operam para encaixá-la como uma importante peça de estruturação da sociedade. A luta pela escola pública, gratuita e universal foi evocada, na idade Moderna, a partir do discurso proferido pela ascensão da burguesia, para reprodução de seus constructos ideológicos, utilizando-se do Estado de Direito para inculcação cultural dos seus símbolos e valores. Em contrapartida, o homem é, também, protagonista da sua história, assimilando, agindo e reagindo na sua relação com seus pares e com a natureza. Nesse trabalho será demarcado a concepção de educação trazida por Paulo Freire (1996) por designar um papel dialético à escola formal, dando relevância no que se passa dentro dos seus muros e ressoa fora deles, no que se aprende e se educa nesse importante espaço de tensão.

Como sabemos, esse lócus envolve alguns mitos e muitas esperanças, por isso, a educação formal ministrada na escola ainda é muito cobiçada por todas as classes sociais, seja pelo sonho de ascensão, domínio, liberdade ou transformação. A ausência de neutralidade que cabe à educação lhe oferece um desígnio, consciente ou inconsciente, como um dos importantes instrumentos para o homem agir no meio social. Por isso, a sua função bivalente amedronta os que dirigem e detém o poder, assumindo um caráter de suma importância a cada reorganização da sociedade.

A cada transformação das forças produtivas da sociedade, em diferentes momentos históricos, redimensiona-se a visão de homem que pretende formar para tentar adequar às mudanças. A educação como uma das mola-mestra da formação humana é retomada como uma forte aliada do processo. A conceituação apontada por Freire (1996), como prática social humana, evidencia sua dimensão dialética e prioritária podendo subjugar ou emancipar crianças, jovens e adultos. 
Ao esboçar o conceito de política é sempre bom revisitar a acepção clássica do termo, originado do adjetivo polis - politikés - designa tudo referente à cidade, por consequência, ao urbano, civil, público, social. Partindo desta acepção, política, é um campo de "estudo da esfera das atividades humanas articuladas às coisas do Estado". Na sociedade capitalista moderna, o Estado, representa o poder político que atua na proibição, no ordenamento, no planejamento, na legislação e/ou intervenção, sempre tentando mediar as forças sociais em confronto, "com efeitos vinculadores a um grupo social definido e ao exercício do domínio exclusivo sobre um território e da defesa de suas fronteiras" (SHIROMA, p. 7, 2004).

Azevedo (2004) acrescenta algo muito pertinente no posicionamento da educação como política pública: parte do princípio que "a política educacional definida como policy - programa de ação - é um fenômeno que se produz no contexto das relações de poder expressas na politics - política no sentido da dominação - e, portanto, no contexto das relações socais que plasmam as assimetrias, a exclusão e as desigualdades que se configuram na sociedade e no nosso objeto" (Azevedo, VIII, 2004.). Assim, a política educacional formulada para cada nível de ensino, requer um olhar crítico frente à reconfiguração sócio-econômica do seu tempo, pois retrata o conjunto de significações de uma dado momento histórico e social de uma realidade.

Com base nas considerações de Shiroma e Azevedo (2004), bem como Paulo Freire (1996), deduz-se que a política educacional como um programa de ação que se materializa através da ação das instituições do Estado, tem na máquina governamental o principal veículo para concretizar os objetivos de reestruturação da sociedade, o que atribui à educação seu caráter de política pública. A política educacional é um dos meios para projetar o acesso e a formação de diversos tipos de pessoas que a sociedade necessita, definindo a forma e o conteúdo do saber a ser ensinado para legitimar e assegurar os princípios ideológicos da sociedade que está sendo criada ou reedificada. Seguindo essa premissa, toda política educacional é carregada de intenções. Quando lemos as entrelinhas de suas intenções conhecemos que tipo de homem e sociedade pretende formar.

Toda a política educacional tem, a priori, o objetivo de "transformar", por intermédio da educação, os indivíduos e a sociedade em algo melhor, mas como sabemos, determinados grupos sociais e ideologia a define. Ao se materializar, pode educar indivíduos como massa de manobra para os processos produtivos emergentes da estrutura econômica vigente ou trazer à tona a exploração para imputar a consciência crítica para resistir, reivindicar e lutar por condições humanas menos desiguais.

Azevedo (2004) propõe uma abordagem analítica no espaço de interseção entre as abordagens liberalista e funcionalista, por ambas não atenderem à educação como uma política pública. A vertente liberalista fundada no ideário de Adam Smith e revigorada a partir da década de 1970 por Hayek (1944) e Friedman(1980), através do neoliberalismo, apregoava a desregulamentação do Estado nas políticas sociais e o mercado como regulador e distribuidor de renda, o que causou um fosso social gigantesco, acirrando ainda mais a desigualdade.

A abordagem funcionalista fundamentada nas ideias de Durkheim, ainda segundo a autora, ao super valorizar a educação, buscou posicionar a escola em um lugar privilegiado, mas sempre com intuito 
de manter a ordem vigente para funcionar de forma harmoniosa e omitir as estruturas macros que regem a relação entre capital e trabalho. A interseção da autora transpõe, também, a lógica marxista na medida em que acolhe a exploração e desigualdades denunciadas por Marx, apontando como saída do quase determinismo provocado pelas estruturas econômicas, propondo uma acepção ampliada de Estado, na visão de Gramsci:

[...] numa acepção 'ampliada' do Estado como concebeu Gramsci: como instância superestrutural que engloba a sociedade política - locus da dominação pela força e consentimento - e a sociedade civil - o lugar desta dominação pelo consentimento" (GRAMSCI apud AZEVEDO 2004, p. 59).

Semeraro (1999) mostra dificuldade dessa dimensão política da sociedade civil na visão gramsciana e ao mesmo tempo a importância de criar condições de saída do fatalismo e submissão das classes trabalhadoras, a fim de desenvolver forças de sua subjetividade para alcançar uma sociedade construída pela participação de todos:

Ao direfenciar-se da sociedade política, a sociedade civil reabre a questão do poder, uma vez que “a base histórica do Estado foi deslocada' e, com o surgimento de complexas superestruturas, se dilatam os epaços para a determinação de uma nova hegemonia. Nas novas estratégias de luta, portanto, era necessário partir duma concepção ampliada de Estado e sociedade (SEMERARO, 1999, p. 27).

Como a política educacional está vinculada à reestruturação da sociedade de um dado momento histórico, a sua construção por sua vez, está alicerçada pelas forças sociais que tem "poder de voz e decisão". Para que os anseios coletivos alcancem as instituições do Estado, consolidando em políticas ou programas de ação que atendam à maioria de forma digna e universal, faz-se necessário que as pessoas alijadas do processo de construção e acesso dos bens materiais de consumo e sociais participem, ocupando os espaços de legitimação.

A educação, como prática social humana pode agir e intervir para reverter a política educacional em uma política pública mais universalista. Para tanto, é preciso ultrapassar os interesses individuais e atuar na dimensão de favorecer o bem comum de todos os sujeitos sociais que constroem a sociedade, promovendo a consciência política das condições concretas do sujeito, seu papel assume uma dimensão importante de minimizar ou superar a injustiças sociais.

\section{Considerações Finais}

O desafio na contemporaneidade é estabelecermos atitudes de engajamento radical onde os interesses pessoais sejam associados à vontade coletiva do grupo social ao qual fazemos parte. A luta por dias melhores privilegie valores como colaboração, cooperação, solidariedade para conduzir a ação coletiva dos seres humanos, a fim de criar práticas sociais criativas e transformadoras.

Para as mulheres a equidade em relação ao homem tão almejada perpassa pela valorização de sua existência enquanto sujeito pensante, que contribui economicamente e culturalmente na construção da humanidade. O desejo é de partilhar a maternidade com o homem ou sem o homem, mas garantindo o 
acesso a educação dos seus filhos desde do nascimento, pois as próprias mudanças do mundo do trabalho não cabe mais uma mulher dedicada exclusivamente a educação dos filhos dentro do espaço doméstico.

A "modernidade tardia" traz consigo contradições nas suas práticas sociais, mas a capacidade reflexiva, inquietante e de sobrevivência dos sujeitos sociais convida a uma reviravolta, a fim de conquistar dias melhores.

\section{Referências}

AZEVEDO, Janete M. Lins. A Educação como politica pública. Campinas, SP: Autores Associados, 2004, 3. ed. (coleção polêmicas do nosso tempo, vol. 56).

BERMAN, Marshall. Modernidade ontem, hoje e amanhã In: Tudo que é sólido desmancha no ar: a aventura da modernidade. São Paulo, Companhia das letras, 1986.

BOBBIO, Norberto. Estado, governo, sociedade: por uma teoria geral da política. Tradução Marco Aurélio Nogueira. Rio de Janeiro: Paz e Terra, 1987.

BONETI, Lindomar Wessler. Políticas públicas por dentro. Ijuí: Editora Unijuí, 2006.

FREIRE, Paulo. Pedagogia da autonomia: saberes necessários à prática educativa. São Paulo: Paz e Terra, 1996.(Coleção Leitura).

FRIEDMAN, Milton e FRIEDMAN, Rose. Liberdade de escolher. Trad. Ruy Jungman. Rio de Janeiro: Editora Record, 1980.

GONH, Maria da Glória. Movimentos sociais e educaşão. 6. ed. Revista. São Paulo: Cortez, 2005.

Teorias sobre movimentos sociais na era da globalização: a mobilização política - MP In: Teoria dos movimentos sociais. São Paulo: Edições Loyola, 1985.

HALL Stuart. A identidade cultural na pós-modernidade. Trad. Tomaz Tadeu da Silva, Guacira Lopes Louro. 10 ed. Rio de Janeiro, DP\&A, 2005.

HAYEK, Friederich August von. O caminho da servidão. Tradução de Leonel Vallandro. 2 ed. São Paulo, Globo, 1997.

HOBSBAWN, Eric J. O século: vista aérea; A era da guerra total; Rumo ao milênio In: Era dos extremos: 0 breve século XX (1914-1991). Tradução Marcos Santarrita. São Paulo: Companhia das letras, 1995. Páginas (11-26), Cap.1 e 19.

MACIEL, David. Estado e poder político em Gramsci In: Estado e poder político: da afirmação da hegemonia burguesa à defesa da revolução social. Organização: Walmir Barbosa. Goiânia: Editora da UCG, 2004.

MANZINI-COVRE, Maria de Lourdes. O que é cidadania. São Paulo: Brasiliense, 2006.

MARX, K. Prefácio In: Para contribuição à crítica da economia politica. São Paulo: Abril Cultural. 1982.

MAX , K. \& Engels, F. O manifesto comunista. Trad. Maria Lúcia Como. Rio de Janeiro: Paz e Terra, 1998.

MONTAÑO, Carlos. Terceiro setor e questão social: crítica ao padrão emergente de intervenção social. São Paulo: Cortez, 2002.

MOSS, Peter. Qualidade na educação da primeira infância: perspectivas pós-modernas. Gunilla Dahlberg (org.). trad. Magda França Lopes. Porto alegre: Artmed, 2003.

OLIVEIRA, Zilma M. (org.). Creches: faz de conta \& cia. Rio de Janeiro: Vozes, 1996.

ROUSSEAU, Jean-Jacques. Discurso sobre a origem e os fundamentos da desigualdade entre os homens. Martin Claret, São Paulo, 2005.

SANCHES, Emilia Cipriano. Creche: realidade e ambigüidades. Petrópolis, RJ: vozes, 2003. 
SEMERARO, Giovanni. Gramsci e a sociedade civil; cultura e educação para a democracia. Petrópolis, RJ: Vozes, 1999.

SENNET, Richard. O declínio do homem público: as tiranias da intimidade. Tradução Ligya Araújo Watanabe. São Paulo: Companhia das letras, 1988.

SHIROMA, Eneida Oto et all. Politica educacional. Rio de Janeiro: DP\&A, 2004, 3. ed.

VIEIRA, Evaldo. Os direitos sociais e a política social. São Paulo: Cortez, 2004.

\section{Notas:}

1 Universidade Federal da Bahia. Escola de Dança. Doutora em Difusão Conhecimento pelo Programa de Doutorado Multiinstitucional e Multidisciplinar em Difusão do Conhecimento da Universidade Federal da Bahia, Mestrado em Educação e Contemporaneidade pela Universidade do Estado da Bahia, especialista em Metodologia do Ensino Superior pela Faculdade de Educação Olga Metting e Pedagoga pela Universidade Federal da Bahia. Professora da carreira do Ensino Básico, Técnico, Tecnológico da Universidade Federal da Bahia desde 1997, com experiência na creche da instituição como docente e professora do Curso de Especialização Docência na Educação Infantil da Secretaria da Educação Básica/MEC coordenado pela FACED/UFBA. Estuda políticas de Educação Infantil, aspectos relacionados ao cotidiano pedagógico das creches e préescolas, cultura infantil, tecnologias, mediação e formação do educador. ORCID: $\underline{\text { https://orcid.org/0000-0002-9429-8703 }}$ Email: analuciaufba@gmail.com

Recebido em: 31/10/2018

Aceito em: 13/05/2019 